\title{
PENGARUH BUDAYA ORGANISASI, GAYA KEPEMIMPINAN TRANSFORMASIONAL, DAN MOTIVASI KARYAWAN TERHADAP KOMITMEN ORGANISASIONAL PT. GED DENPASAR
}

\author{
Sri Purnamasari ${ }^{1}$ \\ Anak Agung Ayu Sriathi ${ }^{2}$ \\ ${ }^{1,2}$ Fakultas Ekonomi dan Bisnis Universitas Udayana (Unud), Bali, Indonesia \\ e-mail: rimapurnamasari5@gmail.com
}

\begin{abstract}
ABSTRAK
Penelitian ini berujuan untuk mengetahui pengaruh budaya organisasi, gaya kepemimpinan transformasional dan motivasi karyawan terhadap komitmen organisasional. Penelitian ini dilakukan di PT. Ganesha Emas Dwipa Cabang Denpasar. Jumlah target populasi penelitian ini sebanyak 33 responden Pengumpulan data dilakukan melalui observasi, wawancara dan kuesioner. Penelitian ini menggunakan uji instrumen dengan menggunakan teknik analisis regresi linear berganda. Berdasarkan hasil analisis ditemukan bahwa budaya organisasi, gaya kepemimpinan transformasional, dan motivasi karyawan secara simultan berpengaruh positif dan signifikan terhadap komitmen organisasional. Secara parsial budaya organisasi berpengaruh positif dan signifikan terhadap komitmen organisasional. Gaya kepemimpinan transformasional secara parsial berpengaruh positif dan signifikan terhadap komitmen organisasional, sedangkan motivasi karyawan secara parsial berpengaruh positif dan signifikan terhadap komitmen organisasional. Komitmen dapat tercapai apabila individu dalam organisasi sadar akan hak dan kewajibannya dalam organisasi tanpa melihat jabatan dan kedudukan masing - masing individu, karena pencapaian tujuan organisasi merupakan hasil kerja semua anggota organisasi yang bersifat kolektif.

Kata kunci: budaya organisasi, gaya kepemimpinan transformasional, motivasi, komitmen organisasional
\end{abstract}

\begin{abstract}
The purpose of this research is to know the influence of organizational culture, transformational leadership style and employee motivation toward organizational commitment. This research was conducted at PT. Ganesha Emas Dwipa Denpasar Branch. The number of target population of this study as much as 33 respondents Data collection is done through observation, interviews and questionnaires. This study uses instrument test by using multiple linear regression analysis technique. Based on the analysis results found that organizational culture, transformational leadership style, and employee motivation simultaneously have a positive and significant impact on organizational commitment. Partially organizational culture has a positive and significant effect on organizational commitment. Transformational leadership style partially positive and significant impact on organizational commitment, while employee motivation partially have a positive and significant impact on organizational commitment. Commitment can be achieved if individuals in the organization are aware of their rights and obligations in the organization regardless of position and position of each individual, because the achievement of organizational goals is the result of the work of all members of the organization that are collective.
\end{abstract}

Keywords: organizational culture, transformational leadership style, motivation, organizational commitment 


\section{PENDAHULUAN}

Di era modern ini banyak perusahaan yang berlomba - lomba untuk menjadi perusahaan yang unggul dalam persaingan. Kemajuan teknologi dan persaingan yang ketat di era globalisasi membuat perusahaan akan selalu melakukan adaptasi terhadap perubahan - perubahan yang terjadi pada lingkungan bisnis. Untuk merespon hal tersebut, maka perusahaan - perusahaan menjadikan sumber daya manusia yang dimilikinya sebagai fokus utama mereka. Hal ini dikarenakan sumber daya manusia merupakan "jantung" dari sebuah perusahaan dalam proses pencapaian tujuan perusahaan. Apabila sumber daya manusia yang dimiliki menghasilkan kinerja yang diharapkan sesuai dengan ekspektasi perusahaan, maka akan membuat perusahaan semakin mudah mencapai tujuan mereka. Berhasil atau tidaknya perusahaan dalam memenangkan kompetisi dapat dilihat dari keberlangsungan hidup perusahaan itu sendiri. Dengan melihat hal tersebut dapat diketahui bahwa perusahaan memiliki strategi yang baik di dalam beradaptasi dengan lingkungan mereka. Tidak hanya memiliki strategi yang baik saja melainkan untuk mendukung strategi tersebut dibutuhkan sumber daya manusia yang berkualitas guna mendukung strategi mereka. Sumber daya manusia atau karyawan yang berkualitas akan dapat menempatkan perusahaan pada jalur persaingan atau bahkan dapat menjadi leader dalam persaingan.

Kualitas sumber daya manusia di dalam perusahaan harus terus dikembangkan oleh perusahaan yang disesuaikan dengan perkembangan zaman saat ini. Dengan begitu para karyawan dapat melaksanakan pekerjaannya secara profesional, bertanggung jawab, serta memiliki attitude yang baik guna dapat 
membantu memenuhi kebutuhan konsumen yang semakin kompleks dalam era globalisasi ini.

Komitmen organisasional adalah sikap yang mencerminkan loyalitas karyawan terhadap organisasi mereka dan proses yang berkelanjutan di mana peserta organisasi mengekspresikan kepedulian mereka terhadap organisasi, kesuksesan, dan kesejahteraan (Luthans, 2005:217). Komitmen organisasional ini juga dapat diartikan sebagai dorongan emosional diri dalam arti positif. Di mana pegawai atau karyawan yang ingin kariernya maju berkomitmen untuk mengejar keunggulan dan meraih prestasi, dan karyawan yang merasa penting terhadap pelayanan berkomitmen untuk meningkatkan kompetensi. Ini adalah ekspresi yang menunjukkan bahwa mereka percaya dan peduli terhadap organisasinya. Tanpa komitmen, pegawai atau karyawan tidak memiliki usaha yang maksimal dalam meningkatkan kompetensi serta rendahnya motivasi dalam mencapai tujuan perusahaan atau organisasi.

Terbentuknya komitmen organisasional, Lok, Peter dan Crawford (2004) menyatakan bahwa budaya organisasi merupakan faktor yang sangat berpengaruh penting terhadap terbentuknya komitmen organisasional. Budaya organisasi merupakan pola dari keyakinan, perilaku, asumsi, dan nilai - nilai yang dimiliki bersama. Budaya organisasi membentuk cara berperilaku dan berinteraksi anggota organisasi dan mempengaruhi cara kerja mereka. Pada gilirannya, budaya organisasi ini diharapkan akan mampu menciptakan lingkungan yang kondusif bagi perbaikan kinerja individu dan organisasi Susanto 2011 (dalam Emron et al., 2014:118). Budaya yang kuat memiliki pengaruh yang kuat dalam pembentukan 
Sri Purnamasari, Pengaruh Budaya Organisasi...

perilaku anggota suatu organisasi. Semakin banyak anggota yang menerima nilai - nilai bersama tersebut, maka akan semakin kuat budayanya. Dengan terciptanya budaya yang kuat, anggota organisasi akan menimbulkan sense of belonging yang dapat menciptakan komitmen terhadap organisasinya. Sehingga budaya organisasi menjadi suatu hal yang penting untuk diperhatikan dalam meningkatkan komitmen organisasional.

Kepemimpinan merupakan hal yang wajib dimiliki oleh seorang pemimpin. Hal ini dikarenakan kepemimpinan adalah kemampuan yang dimiliki oleh seseorang untuk mempengaruhi orang lain agar dapat bekerja guna mencapai tujuan dan sasaran. Menurut Wicaksono (2014) gaya kepemimpinan adalah pola tingkah laku yang dilakukan dengan mengintegrasikan tujuan organisasi dengan tujuan individu untuk mencapai tujuan yang diinginkan. Seorang pemimpin di dalam memimpin pasti memiliki gaya kepemimpinan yang sesuai dengan situasi dan kondisi karyawan yang dipimpinnya. Gaya kepemimpinan transformasional merupakan gaya kepemimpinan yang menginspirasi pengikutnya untuk terlibat, berkomitmen, dan memiliki visi serta tujuan bagi organisasi mereka, mendorong pengikutnya menjadi inovatif di dalam memecahkan masalah organisasi, dan mendukung pengikutnya untuk memiliki kompetensi dalam kepemimpinan melalui pembinaan dan pengawasan (Indrayanto et al., 2013).

Kepemimpinan transformasional pada prinsipnya memotivasi bawahannya untuk berbuat lebih baik dari apa yang biasa dilakukan, dengan kata lain dapat meningkatkan kepercayaan atau keyakinan diri bawahan yang akan berpengaruh pada peningkatan kerja. Hal penting lain dalam mengelola sumber daya manusia 
di dalam organisasi adalah melalui motivasi. Motivasi merupakan proses yang mendorong, dan mengarahkan perilaku manusia ke arah pencapaian tujuan. Motivasi mempunyai peran penting bagi karyawan maupun para pemimpin, karena dengan adanya motivasi yang tinggi akan berdampak pada pekerjaan yang dilakukan dengan bersemangat di mana akan dapat tercapainya tujuan yang diinginkan secara efisien dan efektif menurut Muslih (2012). Dengan melihat penjelasan tersebut maka dapat disimpulkan bahwa motivasi merupakan dorongan yang berasal dari dalam maupun luar diri seorang individu untuk menghasilkan output guna mencapai tujuan yang ditentukan.

PT. Ganesha Emas Dwipa merupakan perusahaan yang berkembang dibidang courier dan cargo di mana perusahaan ini telah berdiri sejak tahun 2008 di Denpasar dan bekerjasama dengan PT. Garuda Indonesia, maka dibentuk perusahaan jasa layanan pengiriman udara door to out door service. Perusahaan ini melayani pengirimin barang dan dokumen secara domestik dan internasional. PT. Ganesha Emas Dwipa memiliki 9 cabang yaitu di Denpasar, Bandung, Balikpapan, Yogyakarta, Makassar, Medan, Pekanbaru, Solo, dan Surabaya.

Berdasarkan hasil wawancara dengan lima belas orang karyawan di PT. Ganesha Emas Dwipa Cabang Denpasar, terdapat permasalahan yang menimbulkan rendahnya komitmen karyawan dalam berorganisasi. Hal tersebut terlihat dari rendahnya kontribusi karyawan dalam bekerja yang disebabkan oleh ketidaksesuaian pekerjaan yang diberikan kepada karyawan, sehingga menyebabkan beberapa karyawan tidak sanggup mengerjakan banyaknya pekerjaan yang diberikan demi pencapaian tujuan perusahaan tersebut. Hal ini 
Sri Purnamasari, Pengaruh Budaya Organisasi...

mengakibatkan karyawan lebih memilih untuk meninggalkan perusahaan karena tidak kuat dengan keadaan yang terjadi di perusahaan. Permasalahan lain yang terjadi yaitu masalah gaji yang dibayarkan tidak tepat pada waktunya dan gaji yang dibayarkan tidak sesuai dengan pekerjaan yang telah dilakukan oleh karyawan, sehingga karyawan memilih untuk keluar dari pekerjaannya sebelum masa kontraknya habis. Banyaknya masalah serta tekanan yang ada di dalam perusahaan tersebut menyebabkan rendahnya komitmen organisasional yang dimiliki oleh para karyawan.

Permasalahan lain yang terjadi adalah banyaknya karyawan yang melakukan pelanggaran - pelanggaran aturan yang sudah ditentukan oleh perusahaan sebagai contoh, seringnya karyawan yang datang terlambat, kurangnya dorongan dari pemimpin kepada karyawannya untuk menyelesaikan tugas yang diberikan secara maksimal, di mana hal ini menyebabkan turunnya komitmen organisasional karyawan, serta kurangnya kesempatan bagi karyawan dalam mendapatkan jabatan yang lebih tinggi yang mana hal ini dapat menyebabkan turunnya motivasi karyawan dalam mengerjakan tugas yang diberikan. Adapun hasil wawancara yang telah dilakukan peneliti kepada lima belas orang karyawan di PT. Ganesha Emas Dwipa cabang Denpasar disajikan dalam Tabel 1 Sebagai berikut,

Tabel 1.

Hasil Wawancara Awal Mengenai Komitmen Organisasional di PT. Ganesha Emas Dwipa Cabang Denpasar.

\begin{tabular}{cllllll}
\hline No. & \multicolumn{1}{c}{ Pernyatan } & STS & TS & N & S & SS \\
\hline 1. & Saya merasa senang terlibat dalam organisasi & 8 & 2 & 5 & \\
2. & Saya ingin tetap tinggal dalam organisasi & 7 & 5 & 3 & \\
3. & $\begin{array}{l}\text { Saya bertanggung jawab untuk melakukan } \\
\text { pekerjaan di organisasi }\end{array}$ & 4 & 5 & 6 & \\
\hline
\end{tabular}

Sumber: PT. Ganesha Emas Dwipa Cabang Denpasar, 2017 
Berdasarkan latar belakang yang telah diuraikan, maka penelitian ini bertujuan untuk menganalisis pengaruh budaya organisasi, gaya kepemimpinan, dan motivasi karyawan terhadap komitmen organisasional di PT. Ganesha Emas Dwipa Cabang Denpasar. Penelitian ini memiliki dua keguaan, yaitu kegunaan teoritis dan kegunaan praktis. Kegunaan teoritis dari penelitain ini, mahasiswa diharpkan mampu menerapkan ilmu yang telah dipelajari melalui penelitian ini, sehingga dapat mengetahui pengaruh budaya organisasi, kepemimpinan transformasional dan motivasi karyawan terhadap komitmen organisasional yang nantinya dapat berperan untuk keefektifan kerja dan kesuksesan perusahaan untuk ke depannya. Kegunaan Praktis berupa penelitian ini diharapkan dapat membantu sebuah perusahaan yang mempunyai masalah yang hampir sama dengan bidang ini untuk membantu memecahkan masalah dengan memberikan masukan tentang pentingnya budaya organisasi, kepemimpinan transformasional dan motivasi karyawan terhadap komitmen organisasional yang nantinya dapat digunakan untuk mencapai tujuan perusahaan tersebut.

Komitmen organisasional adalah sikap yang mencerminkan loyalitas karyawan terhadap organisasi mereka dan proses yang berkelanjutan di mana peserta organisasi mengekspresikan kepedulian mereka terhadap organisasi, kesuksesan, dan kesejahteraan (Luthans, 2005:217). Komitmen organisasional ini juga dapat diartikan sebagai dorongan emosional diri dalam arti positif. Di mana pegawai atau karyawan yang ingin kariernya maju berkomitmen untuk mengejar keunggulan dan meraih prestasi, dan karyawan yang merasa penting terhadap pelayanan berkomitmen untuk meningkatkan kompetensi. Komitmen dapat 
tercapai apabila individu dalam organisasi sadar akan hak dan kewajibannya dalam organisasi tanpa melihat jabatan dan kedudukan masing - masing individu, karena pencapaian tujuan organisasi merupakan hasil kerja semua anggota organisasi yang bersifat kolektif (ChristinaT.S, 2012). Komitmen berarti keinginan karyawan untuk tetap mempertahankan keanggotaannya dalam organisasi dan bersedia melakukan usaha yang tinggi bagi pencapaian tujuan organisasi (Darmawan, 2013:171). Komitmen organisasional merupakan suatu keadaan seorang karyawan memihak pada suatu organisasi dan tujuan tujuannya, serta berniat memelihara keanggotaannya dalam suatu organisasi (Robbins \& Timothy, 2008:100). Menurut Schermerhorn (2011) mendefinisikan komitmen organisasional adalah loyalitas seseorang terhadap organisasi. Sedangkan Colquitt, Lepine \& Wesson (2011) menyatakan bahwa komitmen organisasional merupakan keinginan dari seorang karyawan untuk menjadi anggota dari suatu organisasi. Berdasarkan pegertian tersebut, dapat disimpulkan bahwa komitmen organisasional adalah sikap terhadap suatu organisasi dengan keinginan dengan sepenuhnya terlibat untuk melakukan tugas untuk mencapai tujuan organisasi serta keinginannya untuk tetap menjadi anggota disuatu organisasi.

Budaya organisasi merupakan pola dari keyakinan, perilaku, asumsi, dan nilai - nilai yang dimiliki bersama. Budaya organisasi membentuk cara berperilaku dan berinteraksi anggota organisasi dan mempengaruhi cara kerja mereka. Pada gilirannya, budaya organisasi ini diharapkan akan mampu menciptakan lingkungan yang kondusif bagi perbaikan kinerja individu dan 
organisasi Susanto 2011 (dalam Emron et al., 2014:118). Budaya organisasi merupakan nilai - nilai dominan yang didukung oleh organisasi, falsafah yang menuntun kebijaksanaan organisasi terhadap pegawai dan pelanggan, cara suatu pekerjaan dilakukan, asumsi dan kepercayaan dasar yang terdapat diantara anggota organisasi (Stephan P. Robbin, 1996:479). Budaya organisasi mengacu pada sistem makna bersama yang dimiliki oleh anggota yang membedakan organisasi tertentu dari organisasi lain. Dengan demikian budaya organisasi adalah sistem nilai internal yang dipegang teguh oleh anggotanya untuk membedakan organisasi tertentu dengan organisasi lain. Budaya organisasi dapat menjadi fasilitator untuk komitmen organisasi baik untuk anggota organisasi maupu bagi organisasi itu sendiri (Robbins \& Judge, 2011). Budaya organisasi merupakan sistem tindakan bersama, nilai, dan kepercayaan yang berkembang dalam sebuah organisasi dan memandu perilaku anggotanya. Budaya organisasi dipahami sebagai sistem yang diungkapkan dalam organisasi dalam tindakan, nilai, dan kepercayaan sehingga menjadi acuan perilaku anggota dalam organisasi (Schermerhorn, 2011). Budaya organisasi didefinisikan sebagai kumpulan nilai dan kepercayaan bersama yang mendasari identitas suatu organisasi yang mana nilai dan kepercayaan tersebut dapat menjadi fondasi bagi pembentukan identitas di dalam suatu organisasi (Kreitner dan Kenicki, 2010).

Menurut Nelson \& Quick (2012) menjelaskan kepemipinan dalam organisasi adalah proses membimbing dan mengarahkan perilaku sesorang di lingkungan kerja. Sedangkan Colquitt, Lepine \& Wesson (2011) menyatakan bahwa kepemimpinan melibatkan kemampuan seseorang untuk menggunakan 
Sri Purnamasari, Pengaruh Budaya Organisasi...

kekuatan dan pengaruhnya terhadap pengikut mereka yang ingin menjalankan aktivitas mereka untuk mencapai tujuan yang diinginkan. Schein (2004) membedakan kepemimpinan menjadi dua yaitu kepemimpinan transaksional dan kepemimpinan transformasional. Kepemimpinan transaksional merupakan kepemimpinan yang memiliki sifat kontrak antara pemimpin dan pengikutnya. Pengikut bersedia bekerjasama untuk mendapatkan reward. Seorang pemimpin transformasional membentuk kembali pengikutnya dengan menciptakan perubahan dalam tujuan, nilai, kebutuhan, kepercayaan, dan aspirasi. Pemimpin menyelesaikan perubahan ini dengan kosep diri, identitas, dan nilai dari pengikutnya. Menurut Gibson, Ivancevich \& Donnelly (2011) mendefinisikan bahwa kepemimpinan transformasional merupakan kemampuan untuk menginspirasi dan memotivasi pengikutnya untuk mencapai hasil yang lebih baik daripada yang direncanakan. Kepemimpinan transformasional yang kuat dapat mempengaruhi semua anggota, terutama karyawan dalam proses perubahan menuju peningkatan komitmen yang lebih baik. Gaya kepemimpinan transformasional merupakan gaya kepemimpinan yang menginspirasi pengikutnya untuk terlibat, berkomitmen, dan memiliki visi serta tujuan bagi organisasi mereka, mendorong pengikut menjadi inovatif di dalam memecahkan masalah organisasi, dan mendukung pengikut untuk memiliki kompetensi dalam kepemimpinan melalui pembinaan dan pengawasan (Indrayanto et al., 2013). Gaya kepemimpinan merupakan suatu cara yang digunakan pemimpin dalam berinteraksi dengan bawahannya (Tjiptono, 2006:61). Pengikut seorang pemimpin transformasional merasa adanya kepercayaan, kekaguman, kesetiaan, dan hormat 
terhadap pemimpin tersebut, serta mereka termotivasi untuk melakukan lebih dari pada yang awalnya diharapkan terhadap mereka. Pemimpin yang transformasional harus mampu mengajak bawahannya untuk melakukan perubahan dimana perubahan tersebut berpengaruh terhadappekerjaan yang dilakukan para karyawan (Munawaroh, 2011).

Motivasi adalah hal yang berperan penting bagi setiap organisasi untuk mencapai keberhasilan dalam suatu organisasi tersebut (Chintallo \& Mahadeo, 2013). Menurut Chaudhary \& Sharma (2012) pada dasarnya kata motivasi berasal dari "motive". Arti "motif" adalah kebutuhan, kemauan serta keinginan seseorang. Jadi motivasi karyawan berarti proses di mana suaru organisasi memberikan inspirasi kepada karyawannya dalam bentuk penghargaan seperti bonus untuk mencapai tujuan organisasi yang akan dicapainya. Sehingga motivasi merupakan faktor utama yang mempengaruhi sumber daya manusia pada suatu organisasi. Organisasi harus memotivasi karyawan mereka guna tercapainya kinerja yang baik untuk mencapai suatu tujuan dalam organisasi (Azar \& Shafighi, 2013). Karyawan memiliki peran penting dalam persepsi pelanggan tentang perusahaan. Perusahaan mengeluarkan cukup banyak uang agar mendapatkan loyalitas pelanggan namun mereka melupakan cara memotivasi karyawannya. Pelanggan berinteraksi dengan karyawan dan juga membuat agar citra perusahaan selalu melekat di dalam pikiran pelanggan mereka melalui perilaku dan sikap. Perusahaan harus mengalihkan perhatian mereka kepada motivasi kerja karyawan (Ahmad, 2012). Manager juga memiliki peran penting dalam memotivasi karyawan dengan cara meningkatkan kerjasama antar karyawan dan seorang 
Sri Purnamasari, Pengaruh Budaya Organisasi...

manager harus mampu mendorong dan memotivasi karyawannya agar bertanggung jawab dengan pekerjaan mereka. Jadi, motivasi merupakan hal yang penting bagi sebagian manager guna mencapai produktifitas yang maksimal (Ali, Abrar \& Haider, 2012). Motivasi berasal dari kata latin movere yang berarti dorongan atau pemberian daya penggerak yang menciptakan kegairahan kerja seseorang agar mereka mau bekerja sama, bekerja efektif, dan terintegritasi dengan segala upayanya untuk mencapai hasil yang diharapkan (Malayu, 2007:43). Menurut Iqbal et al. (2012) motivasi dan kemampuan karyawan secara bersama - sama berpasrtisipasi dalam pekerjaan yang diberikan yang bertujuan untuk memenuhi tujuan organisasi. Motivasi mempunyai peran penting bagi karyawan maupun para pemimpin, karena dengan adanya motivasi yang tinggi akan berdampak pada pekerjaan yang dilakukan dengan semangat di mana akan dapat tercapainya tujuan yang diinginkan secara efisien dan efektif (Muslih, 2012).

Penelitian oleh Sari dan Witjaksono (2013), Taurisa dan Ratnawati (2012), Purba (2010), Rosyidah (2012), dan Nugroho (2013) menemukan bahwa budaya organisasi berpengaruh positif dan signifikan terhadap komitmen organisasional. Berdasarkan penjelasan diatas, maka dapat dirumuskan hipotesis sebagai berikut:

$\mathrm{H}_{1}$ : Budaya organisasi berpengaruh positif dan signifikan terhadap komitmen organisasional

Hasil penelitian Atmojo (2012), Busra et al. (2011), Kurniawan (2015), Atmojo (2012),dan Dunn et al. (2012) bahwa perilaku pemimpin transformasional secara positif dan signifikan berhubungan dengan komitmen organisasional. Dari 
pernyataan di atas dan penelitian terdahulu maka dapat dirumuskan hipotesis sebagai berikut:

$\mathrm{H}_{2}$ : Gaya Kepemimpinan transformasional berpengaruh positif dan signifikan terhadap komitmen organisasional

Penelitian oleh Devi (2009), uspasari (2013), Sanusi (2012), Puspasari (2014),dan Mahmuda (2011) menemukan bahwasanya motivasi berpengaruh positif terhadap komitmen organisasional. Dari pernyataan di atas dan penelitian terdahulu maka dapat dirumuskan hipotesis sebagai berikut:

$\mathrm{H}_{3}$ : Motivasi berpengaruh positif dan signifikan terhadap komitmen organisasional

Dari kajian pustaka dan hasil penelitian sebelumnya yang telah dipaparkan, maka kerangka konseptual dalam penelitain ini dapat disusun sebagai berikut,

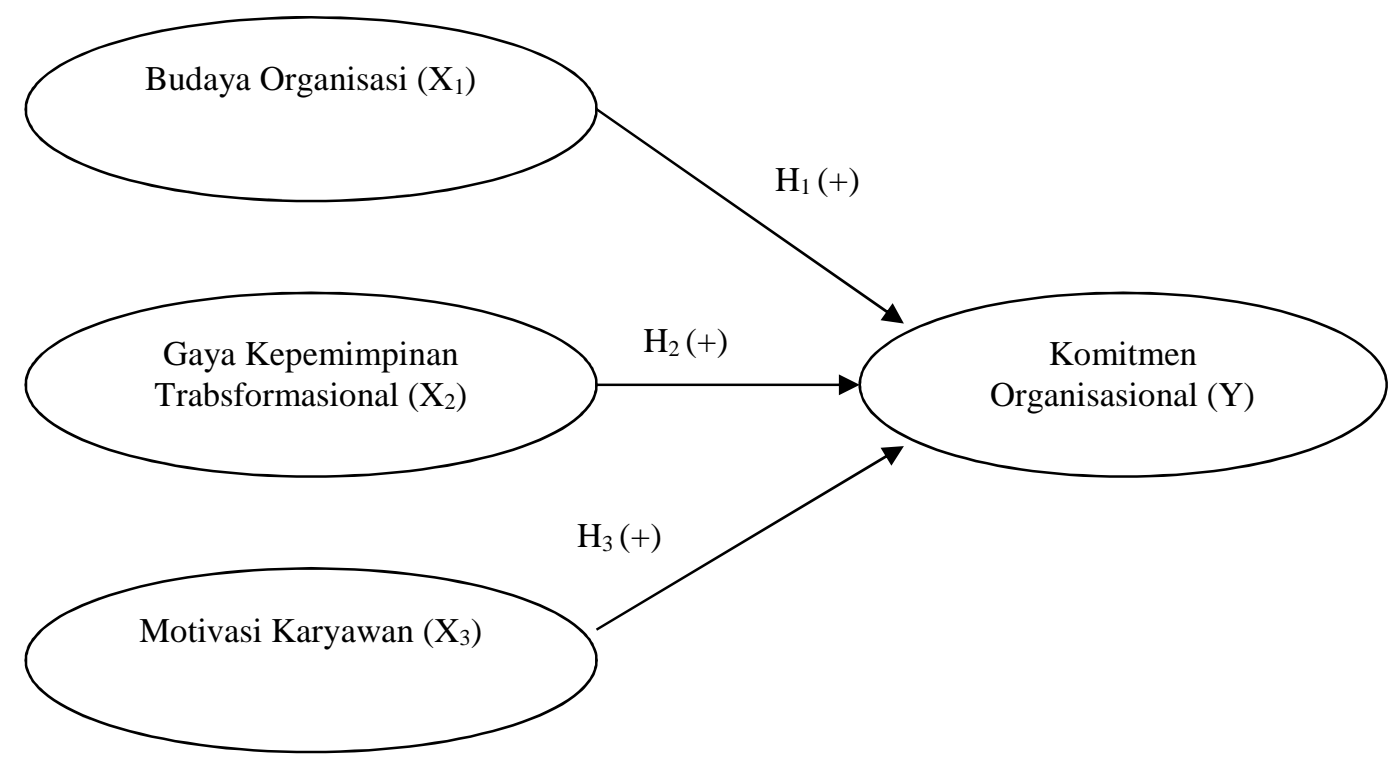

Gambar 1. Kerangka Konseptual 
Sri Purnamasari, Pengaruh Budaya Organisasi...

\section{METODE PENELITIAN}

Pendekatan yang digunakan pada penelitian ini adalah pendekatan asosiatif karena bertujuan untuk menganalisis pengaruh dari beberapa variabel bebas terhadap satu variabel terikat. Penelitian ini dilakukan di PT. Ganesha Emas Dwipa Cabang Denpasar yang bertempat di Jl. Pulau Kawe No.53 Denpasar. Objek penelitian ini yaitu Budaya Organisasi, Gaya Kepemimpinan Transformasional, Motivasi Karyawan dan Komitmen Organisasional di PT. Ganesha Emas Dwipa Cabang Denpasar.

Penelitian ini menggunakan dua jenis variabel, yaitu variabel bebas (X) dan variabel terikat (Y). Variabel bebas dalam peneltian ini berupa budaya organisasi $\left(\mathrm{X}_{1}\right)$, gaya kepemimpinan transformasional $\left(\mathrm{X}_{2}\right)$, dan motivasi karyawan $\left(\mathrm{X}_{3}\right)$. Variabel terikat dalam penelitian ini berupa komitmen organisasional (Y). Dalam mengukur variabel - variabel tersebut, digunakan beberapa indikator yang disajikan dalam Tabel 2 sebagai berikut,

\section{Tabel 2.}

\section{Indikator Penelitian}

\begin{tabular}{|c|c|c|c|}
\hline No. & Variabel & Indikator & Sumber \\
\hline \multirow[t]{3}{*}{1.} & Komitment & 1. $\quad$ Komitment Afektf $\left(\mathrm{Y}_{1}\right)$ & Mayer dan Allen \\
\hline & Organisasional (Y) & 2. Komitmen bekelanjutan $\left(\mathrm{Y}_{2}\right)$ & (1997) \\
\hline & & 3. Komitment normatif $\left(\mathrm{Y}_{3}\right)$ & \\
\hline \multirow[t]{5}{*}{2.} & Budaya organisasi & 1. Kesadaran diri $\left(\mathrm{X}_{1.1}\right)$ & Emron (2014) \\
\hline & $\left(\mathrm{X}_{1}\right)$ & 2. Keagresifan $\left(\mathrm{X}_{1.2}\right)$ & \\
\hline & & 3. Kepribadian $\left(\mathrm{X}_{1.3}\right)$ & \\
\hline & & 4. Peforma $\left(\mathrm{X}_{1.4}\right)$ & \\
\hline & & 5. Orientasi tim $\left(\mathrm{X}_{1.5}\right)$ & \\
\hline \multirow[t]{4}{*}{3.} & Gaya & 1. Idealized influence $\left(\mathrm{X}_{2.1}\right)$ & Bass dan Avolio \\
\hline & kepemimpinan & 2. Individual consideration $\left(\mathrm{X}_{2.1}\right)$ & $(1990)$ \\
\hline & transformasional & 3. Intellectual stimulation $\left(\mathrm{X}_{2.1}\right)$ & \\
\hline & $\left(\mathrm{X}_{2}\right)$ & 4. Inspirational motivation $\left(\mathrm{X}_{2.1}\right)$ & \\
\hline \multirow[t]{4}{*}{4.} & Motivasi $\left(\mathrm{X}_{3}\right)$ & 1. Penempatan kerja yang tepat $\left(\mathrm{X}_{3.1}\right)$ & Ardana et al. \\
\hline & & 2. Kondisi pekerjaan yang menyenangkan $\left(\mathrm{X}_{3.2}\right)$ & (2002) \\
\hline & & 3. Fasilitas rekreasi $\left(\mathrm{X}_{3.3}\right)$ & \\
\hline & & 4. Jaminan kesehatan $\left(\mathrm{X}_{3.4}\right)$ & \\
\hline
\end{tabular}


Populasi pada penelitian ini adalah seluruh karyawan yang bekerja di PT. Ganesha Emas Dwipa Cabang Denpasar yaitu sebanyak 33 orang. Metode penentuan sampel yang digunakan yaitu menggunakan metode sampling jenuh, yang mana semua anggota populasi dijadikan sebagai sampel. Tetapi dalam penelitian ini peneliti meneliti mengenai kepemimpinan, maka pemimpin dalam perusahaan tidak dimasukkan ke dalam sampel. Dengan demikian jumlah sampel yang digunakan dalam penelitian ini adalah sebanyak 32 orang karyawan di PT. Ganesha Emas Dwipa Cabang Denpasar.

Tabel 3.

Jumlah Populasi Karyawan PT. Ganesha Emas Dwipa tahun 2017

\begin{tabular}{clc}
\hline No. & \multicolumn{1}{c}{ Jabatan } & Jumlah Karyawan (Orang) \\
\hline 1. & Direktur and Manager & 2 \\
2. & Costumer service & 4 \\
3. & Operational & 12 \\
4. & Accounting & 8 \\
5. & Dtrace & 4 \\
6. & Sales & 3 \\
& & $\mathbf{3 3}$ \\
\hline
\end{tabular}

Sumber: Manager PT. Ganesha Emas Dwipa, 2017

Metode pengumpulan data yang digunakan dalam penelitian ini ada tiga, yaitu wawancara, kuisioner, dan observasi. Dalam pengumpulan data menggunakan kuesioner, pernyataan yang tertera dalam kuesioner diukur dengan skala Likert, dengan rentang penilaian seperti pada Tabel 4.

Tabel 4.

Alternatif Jawaban Responden

\begin{tabular}{cccc}
\hline No. & Simbol & Alternatif Jawaban & Skor \\
\hline 1. & SS & Sangat Setuju & 5 \\
2. & S & Setuju & 4 \\
3. & N & Netral & 3 \\
4. & TS & Tidak Setuju & 2 \\
5. & STS & Sangat Tidak Setuju & 1 \\
\hline
\end{tabular}

Sumber : Sugiyono, 2010 
Adapun jenis data yang digunakan dalam penelitian ini adalah data kuantitatif dan kualiatif. Data kuantitatif dalam penelitian ini adalah data jumlah karyawan dan data jawaban responden terhadap pernyataan yang terdapat di dalam kuisioner. Data kualitatif dalam penelitian ini adalah sejarah perusahaan, struktur organisasi, maupun pernyataan dari skala likert. Data primer dari penelitian ini diperoleh dari wawancara langsung melalui kuisioner yang disebarkan kepada responden. Penelitian ini tidak menggunakan data sekunder.

Instrument berupa kuesioner, diuji menggunakan uji validitas dan reliabilitas. Uji validitas berujuan unuk memeriksa apakah isi kuisioner sudah tepat untuk mengukur apa yang ingin diukur. Kuesioner dapat dikatakan valid apabila koefisien korelasi positif dan lebih besar dari 0,361 (Sugiono, 2012:178). Uji reliabilitas bertujuan untuk mengetahui konsistensi alat ukur yang digunakan. Nilai suatu instrumen dapat dikatakan reliable bila nilai Alpha Cronbach $\geq 0,6$. Teknik analisis yang digunakan adalah analisis deskriptif, yang bertujuan untuk mengetahui karakteristif responden, dan menguraika jawaban responden. Selain analisis deskriptif, penelitian ini menggunakan teknik analisis regresi linier berganda, uji asumsi klasik, uji F dan uji T.

\section{HASIL DAN PEMBAHASAN}

Data dari hasil penelitian dilakukan terhadap karyawan PT. Ganesha Emas Dwipa cabang Denpasar, maka dapat diketahui gambaran dari karakteristik responden yang meliputi empat aspek yaitu, jenis kelamin, usia, pendidikan terakhir, serta masa kerja. Pada penelitian ini jumlah responden yang digunakan 
adalah sebanyak 32 responden. Karakterisitik responden disajikan dalam Tabel 5 sebagai berikut,

\section{Tabel 5.}

Karakteristik Responden

\begin{tabular}{|c|c|c|c|c|}
\hline No. & Variabel & Klasifikasi & $\begin{array}{l}\text { Jumlah } \\
\text { (Orang) }\end{array}$ & $\begin{array}{c}\text { Persentase } \\
(\%)\end{array}$ \\
\hline \multirow[t]{3}{*}{1.} & Jenis Kelamin & Laki - laki & 23 & 71,9 \\
\hline & & Perempuan & 9 & 28,1 \\
\hline & & Jumlah & 32 & 100,0 \\
\hline \multirow[t]{9}{*}{2.} & Usia & 15-20 tahun & 2 & 0,63 \\
\hline & & 21-25 tahun & 5 & 1,56 \\
\hline & & 26-30 tahun & 4 & 1,25 \\
\hline & & 31-35 tahun & 4 & 1,25 \\
\hline & & 36-40 tahun & 5 & 1,56 \\
\hline & & 41-45 tahun & 6 & 1,87 \\
\hline & & 46-50 tahun & 4 & 1,25 \\
\hline & & 51-55 tahun & 2 & 0,63 \\
\hline & & Jumlah & 32 & 100,0 \\
\hline \multirow[t]{6}{*}{3.} & Pendidikan terakhir & SMA & 20 & 6,25 \\
\hline & & $\mathrm{S} 1$ & 7 & 2,18 \\
\hline & & D1 & 1 & 0,31 \\
\hline & & D3 & 3 & 0,95 \\
\hline & & D4 & 1 & 0,31 \\
\hline & & Jumlah & 32 & 100,0 \\
\hline \multirow[t]{3}{*}{4.} & Masa kerja & $<1$ tahun & 3 & 9,4 \\
\hline & & $1-10$ tahun & 39 & 90,6 \\
\hline & & Jumlah & 32 & 100,0 \\
\hline
\end{tabular}

Sumber : Data diolah, 2018

Tabel 5 menunjukkan bahwa karyawan dengan jenis kelamin laki - laki berjumlah 23 orang atau sebesar 71,9 persen, sedangkang karyawan dengan jenis kelamin perempuan berjumlah 9 orang atau sebesar 28,1 persen. Hal ini menunjukkan bahwa karyawan di PT. Ganesha Emas Dwipa Cabang Denpasar lebih dominan berjenis kelamin laki - laki dibandingkan perempuan. Dalam kategori usia, karyawan yang bekerja di PT. Ganesha Emas Dwipa Cabang Denpasar lebih banyak yang berusia 41-45 tahun yaitu berjumlah 6 orang atau sebesar 1,87 persen. Pada kategori jenjang pendidikan terakhir, dominasi oleh jenjang pendidikan terakhir SMA yang berjumlah 20 orang atau sebesar 6,25 
persen. Pada kategori lama masa kerja, karyawan mayoritas telah bekerja lebih dari 1 tahun yang berjumlah 29 orang atau 90,6 persen.

Tabel 6.

Hasil Uji Validitas dan Reliabilitas

\begin{tabular}{|c|c|c|c|c|}
\hline No. & Variabel & $\begin{array}{c}\text { Item } \\
\text { Pernyataan }\end{array}$ & $\begin{array}{l}\text { Koefisien } \\
\text { koreliasi }\end{array}$ & $\begin{array}{c}\text { Alpha } \\
\text { Cronbach }\end{array}$ \\
\hline \multirow[t]{10}{*}{1.} & Budaya Organisasi & $\mathrm{X}_{1.1}$ & 0,401 & 0,746 \\
\hline & $\left(X_{1}\right)$ & $\mathrm{X}_{1.2}$ & 0,381 & \\
\hline & & $\mathrm{X}_{1.3}$ & 0,374 & \\
\hline & & $\mathrm{X}_{1.4}$ & 0,707 & \\
\hline & & $\mathrm{X}_{1.5}$ & 0,555 & \\
\hline & & $\mathrm{X}_{1.6}$ & 0,682 & \\
\hline & & $\mathrm{X}_{1.7}$ & 0,370 & \\
\hline & & $\mathrm{X}_{1.8}$ & 0,536 & \\
\hline & & $\mathrm{X}_{1.9}$ & 0,394 & \\
\hline & & $\mathrm{X}_{1.10}$ & 0,368 & \\
\hline \multirow[t]{8}{*}{2.} & Gaya Kepemimpinan & $\mathrm{X}_{2.1}$ & 0,757 & 0,734 \\
\hline & Transformasional & $\mathrm{X}_{2.2}$ & 0,510 & \\
\hline & $\left(\mathrm{X}_{2}\right)$ & $\mathrm{X}_{2.3}$ & 0,590 & \\
\hline & & $\mathrm{X}_{2.4}$ & 0,384 & \\
\hline & & $\mathrm{X}_{2.5}$ & 0,441 & \\
\hline & & $\mathrm{X}_{2.6}$ & 0,418 & \\
\hline & & $\mathrm{X}_{2.7}$ & 0,423 & \\
\hline & & $\mathrm{X}_{2.8}$ & 0,628 & \\
\hline \multirow[t]{8}{*}{3.} & Motivasi Karyawan & $\mathrm{X}_{3.1}$ & 0,774 & 0,782 \\
\hline & $\left(\mathrm{X}_{3}\right)$ & $\mathrm{X}_{3.2}$ & 0,785 & \\
\hline & & $\mathrm{X}_{3.3}$ & 0,524 & \\
\hline & & $\mathrm{X}_{3.4}$ & 0,372 & \\
\hline & & $\mathrm{X}_{3.5}$ & 0,819 & \\
\hline & & $\mathrm{X}_{3.6}$ & 0,819 & \\
\hline & & $\mathrm{X}_{3.7}$ & 0,582 & \\
\hline & & $\mathrm{X}_{3.8}$ & 0,388 & \\
\hline \multirow[t]{3}{*}{4.} & Komitmen & $\mathrm{Y}_{1}$ & 0,566 & 0,715 \\
\hline & Organisasional & $\mathrm{Y}_{2}$ & 0,403 & \\
\hline & $(\mathrm{Y})$ & $\mathrm{Y}_{3}$ & 0,806 & \\
\hline
\end{tabular}

Sumber : Data diolah, 2018

Tabel 6 menunjukkan bahwa seluruh indikator dalam variabel budaya organisasi, gaya kepemimpinan transformasional, motivasi karyawan, dan komitmen organisasional memiliki nilai Pearson Correlation $\geq 0,30$ sehingga seluruh indikator tersebut dikatakan telah memenuhi syarat validitas data. Pada hasil uji reliablitas, hasil pada Tabel 6, menunjukkan bahwa keempat instrumen penelitian yaitu budaya organisasi, gaya kepemimpinan transformasional, 
motivasi karyawan, dan komitmen organisasional memiliki koefisien Cronbach's Alpha $\geq 0,60$ sehingga pernyataan pada kuesioner dapat dikatakan reliabel.

Pernyataan dalam kuesioner, diukut dengan menggunakan rentang distribusi frekuensi rumus, sebagai beriku, $1,00-1,79=$ Sangat Rendah $; 1.80-2,50=$ Rendah; 2,51 - 3,30 = Sedang; 3,31 - 4,20 = Tinggi $;$ 4,21 - 5,00 = Sangat Tinggi. Hasil dari penelitian ini dapat mengetahui tanggapan responden dari masing masing indikator dari setiap variabel.

Deskripsi jawaban responden terhadap komitmen organisasional dapat diukur pada Tabel 7 sebagai berikut,

\section{Tabel 7.}

Deskripsi Jawaban Responden Mengenai Komitmen Organisasi

\begin{tabular}{|c|c|c|c|c|c|c|c|c|}
\hline \multirow{2}{*}{ No. } & \multirow{2}{*}{ Pernyataan } & \multicolumn{5}{|c|}{ Proporsi Persepsi Responden } & \multirow{2}{*}{$\begin{array}{c}\text { Rata- } \\
\text { rata }\end{array}$} & \multirow{2}{*}{ Kriteria } \\
\hline & & STS & TS & $\mathbf{N}$ & $\mathbf{S}$ & SS & & \\
\hline 1. & $\begin{array}{l}\text { Saya merasa senang terlibat dalam } \\
\text { organisasi }\left(\mathrm{Y}_{1}\right)\end{array}$ & 0 & 0 & 17 & 15 & 0 & 3,47 & Tinggi \\
\hline 2. & $\begin{array}{l}\text { Saya ingin tetap tinggal dalam } \\
\text { organisasi }\left(\mathrm{Y}_{2}\right)\end{array}$ & 0 & 3 & 23 & 6 & 0 & 3,09 & Tinggi \\
\hline 3. & $\begin{array}{l}\text { Saya bertanggung jawab untuk } \\
\text { melakukan pekerjaan di organisasi } \\
\left(\mathrm{Y}_{3}\right)\end{array}$ & 0 & 0 & 6 & 14 & 12 & 4,19 & Tinggi \\
\hline \multicolumn{7}{|c|}{ Rata-rata keseluruhan variabel komitmen organisasional } & 3,58 & Tinggi \\
\hline
\end{tabular}

Sumber : Data Diolah, 2018

Penjelasan variabel komitmen organisasional pada Tabel 7 yang menunjukkan nilai rata - rata skor melalui 3 butir pernyataan adalah 3,58. Nilai tersebut berarti komitmen di PT. Ganesha Emas Dwipa tergolong kuat. Kondisi komitmen ini terlihat dari pernyataan "Saya bertanggung jawab untuk melakukan pekerjaan di organisasi" sebesar 4,19. Skor tersebut berada pada rentang 3,31 4,20 dalam kategori kuat. Hal ini berarti secara keseluruhan responden setuju bahwa dalam melakukan pekerjaan selalu bertanggung jawab guna mencapai hasil 
Sri Purnamasari, Pengaruh Budaya Organisasi...

yang baik dalam mengerjakan tugas yang telah diberikan. Skor terendah adalah 3.09 yang terletak pada pernyataan "Saya ingin tetap tinggal dalam organisasi".

Tabel 8.

Deksripsi Jawaban Responden Mengenai Budaya Organisasi

\begin{tabular}{|c|c|c|c|c|c|c|c|c|}
\hline \multirow{2}{*}{ No } & \multirow{2}{*}{ Pernyataan } & \multicolumn{5}{|c|}{$\begin{array}{l}\text { Proporsi Persepsi } \\
\text { Responden }\end{array}$} & \multirow{2}{*}{$\begin{array}{c}\text { Rata- } \\
\text { rata }\end{array}$} & \multirow{2}{*}{ Kriteria } \\
\hline & & STS & TS & $\mathbf{N}$ & $\mathbf{S}$ & SS & & \\
\hline 1. & $\begin{array}{l}\text { Saya mendapatkan kepuasan atas } \\
\text { pekerjaan yang saya lakukan }\left(\mathrm{X}_{1.1}\right)\end{array}$ & 0 & 0 & 12 & 19 & 1 & 3,66 & Tinggi \\
\hline 2. & $\begin{array}{l}\text { Saya selalu berusaha untuk } \\
\text { mengembangkan kemampuan saya } \\
\left(\mathrm{X}_{1.2}\right)\end{array}$ & 0 & 0 & 0 & 19 & 13 & 4,41 & $\begin{array}{l}\text { Sangat } \\
\text { Tinggi }\end{array}$ \\
\hline 3. & $\begin{array}{l}\text { Dalam melaksanakan pekerjaan, } \\
\text { saya selalu berusaha untuk tidak } \\
\text { bergantung pada petunjuk } \\
\text { pemimpin }\left(\mathrm{X}_{1.3}\right)\end{array}$ & 0 & 0 & 8 & 10 & 14 & 4,19 & Tinggi \\
\hline 4. & $\begin{array}{l}\text { Saya selalu berusaha untuk } \\
\text { menyelesaikan tugas dengan baik } \\
\left(\mathrm{X}_{1.4}\right)\end{array}$ & 0 & 0 & 1 & 15 & 16 & 4,47 & $\begin{array}{l}\text { Sangat } \\
\text { Tinggi }\end{array}$ \\
\hline 5. & $\begin{array}{l}\text { Karyawan saling memberi salam } \\
\text { saat berjumpa }\left(X_{1.5}\right)\end{array}$ & 0 & 2 & 3 & 20 & 7 & 4,00 & Tinggi \\
\hline 6. & $\begin{array}{l}\text { Ketika melihat orang lain yang } \\
\text { kurang cakap dalam bekerja, saya } \\
\text { selalu membantunya }\left(\mathrm{X}_{1.6}\right)\end{array}$ & 0 & 2 & 20 & 7 & 3 & 3,34 & Tinggi \\
\hline 7. & $\begin{array}{l}\text { Saya selalu mengutamakan kualitas } \\
\text { dalam menyelesaikan pekerjaan } \\
\left(\mathrm{X}_{1.7}\right)\end{array}$ & 0 & 0 & 16 & 13 & 3 & 3,59 & Tinggi \\
\hline 8. & $\begin{array}{l}\text { Saya selalu bekerja dengan efektif } \\
\text { serta efisien }\left(\mathrm{X}_{1.8}\right)\end{array}$ & 0 & 0 & 5 & 16 & 11 & 4,19 & Tinggi \\
\hline 9. & $\begin{array}{l}\text { Dalam mengerjakan tugas tim, } \\
\text { selalu kami diskusikan agar tujuan } \\
\text { masing-masing dapat tercapai }\left(\mathrm{X}_{1.9}\right)\end{array}$ & 0 & 1 & 21 & 9 & 1 & 3,31 & Tinggi \\
\hline 10. & $\begin{array}{l}\text { Setiap ada permasalahan dalam tim } \\
\text { kerja, selalu kami selesaikan dengan } \\
\text { baik }\left(\mathrm{X}_{1.10}\right)\end{array}$ & 0 & 0 & 22 & 7 & 3 & 3,41 & Tinggi \\
\hline & Rata-rata keseluruhan variabel & D & & & & & $\mathbf{3 , 8 6}$ & Tinggi \\
\hline
\end{tabular}

Sumber : Data Diolah, 2018

Penjelasan variabel budaya organisasi pada Tabel 8 yang menunjukkan nilai rata - rata skor melalui 10 butir pernyataan adalah 3,86 . Nilai tersebut berarti budaya organisasi di PT. Ganesha Emas Dwipa tergolong kuat. Kondisi budaya organisasi ini terlihat dari pernyataan "Saya selalu berusaha untuk mengerjakan tugas dengan baik" sebesar 4,47. Skor tersebut berada pada rentang 4,21 - 5,00 dalam kategori sangat kuat. Hal ini berarti secara keseluruhan responden setuju 
bahwa dalam mengerjakan tugas, mereka berusaha untuk mengerjakannya secara baik guna tercapainya hasil yang memuaskan. Skor terendah adalah 3.31 yang terletak pada pernyataan "Dalam mengerjakan tugas tim, selalu kami diskusikan agar tujuan masing - masing dapat tercapai”.

Tabel 9.

Deskripsi Jawaban Responden Mengenai Gaya Kepemimpinan Transformasional

\begin{tabular}{|c|c|c|c|c|c|c|c|c|}
\hline \multirow[b]{2}{*}{ No } & \multirow[b]{2}{*}{ Pernyataan } & \multicolumn{5}{|c|}{ Proporsi Persepsi Responden } & \multirow{2}{*}{$\begin{array}{l}\text { Rata- } \\
\text { rata }\end{array}$} & \multirow[b]{2}{*}{ Kriteria } \\
\hline & & STS & TS & $\mathbf{N}$ & $\mathbf{S}$ & SS & & \\
\hline 1. & $\begin{array}{l}\text { Pemimpin saya } \begin{array}{l}\text { rela mengorbankan } \\
\text { kepentingan pribadinya } \\
\text { kepentingan organisasi }\left(\mathrm{X}_{2.1}\right)\end{array} \\
\end{array}$ & 2 & 1 & 22 & 7 & 0 & & Sedang \\
\hline 2. & $\begin{array}{l}\text { Tindakan-tindakan yang dilakukan } \\
\text { pemimpin saya menimbulkan rasa } \\
\text { hormat saya kepadanya }\left(\mathrm{X}_{2.2}\right)\end{array}$ & 0 & 2 & 20 & 8 & 2 & 3,31 & Tinggi \\
\hline 3. & $\begin{array}{l}\text { Pemimpin saya selalu memberikan } \\
\text { pelatihan untuk mengembangkan } \\
\text { karir karyawannya }\left(\mathrm{X}_{2.3}\right)\end{array}$ & 0 & 3 & 23 & 6 & 0 & 3,09 & Sedang \\
\hline 4. & $\begin{array}{l}\text { Pemimpin saya selalu memperhatikan } \\
\text { ketersediaan sarana, prasarana yang } \\
\text { memadai untuk mendukung } \\
\text { pelaksanaan kerja karyawannya }\left(\mathrm{X}_{2.4}\right)\end{array}$ & 0 & 0 & 8 & 11 & 13 & 4,16 & Tinggi \\
\hline 5. & $\begin{array}{l}\text { Pemimpin saya mampu mendorong } \\
\text { karyawannya untuk lebih kreatif } \\
\text { dalam melaksanakan tugas }\left(\mathrm{X}_{2.5}\right)\end{array}$ & 0 & 0 & 27 & 5 & 0 & 3,16 & Sedang \\
\hline 6. & $\begin{array}{l}\text { Pemimpin saya mampu mendorong } \\
\text { karyawannya untuk melakukan } \\
\text { berbagai inovasi yang berkaitan } \\
\text { dengan tugas }\left(\mathrm{X}_{2.6}\right)\end{array}$ & 0 & 0 & 29 & 3 & 0 & 3,09 & Sedang \\
\hline 7. & $\begin{array}{l}\text { Pemimpin saya mampu memberikan } \\
\text { motivasi kepada karyawannya untuk } \\
\text { bekerja sesuai dengan tujuan } \\
\text { perusahaan }\left(\mathrm{X}_{2.7}\right)\end{array}$ & 0 & 0 & 8 & 24 & 0 & 3,75 & Tinggi \\
\hline 8. & $\begin{array}{l}\text { Pemimpin saya mampu memberikan } \\
\text { motivasi untuk meningkatkan } \\
\text { semangat kerja karyawannya }\left(\mathrm{X}_{2.8}\right)\end{array}$ & 0 & 1 & 8 & 20 & 3 & 3,78 & Tinggi \\
\hline & ata-rata keseluruhan variabel gaya ke & mim & & & : & & $\mathbf{3 , 4 3}$ & Tinggi \\
\hline
\end{tabular}

Sumber : Data Diolah, 2018

Penjelasan variabel gaya kepemimpinan transformasional pada Tabel 9 yang menunjukkan nilai rata - rata skor melalui 8 butir pernyataan adalah 3,43 . Nilai tersebut berarti gaya kepemimpinan transformasional di PT. Ganesha Emas Dwipa tergolong baik. Kondisi gaya kepemimpinan transformasional ini terlihat 
Sri Purnamasari, Pengaruh Budaya Organisasi...

dari pernyataan "Pemimpin saya selalu memperhatikan ketersediaan sarana, prasarana yang memadai untuk mendukung pelaksanaan kerja karyawannya" sebesar 4,16. Skor tersebut berada pada rentang 3,31-4,20 dalam kategori sangat baik. Hal ini berarti secara keseluruhan responden setuju bahwa ketersediaan saran dan prasarana mampu mendukung pelaksanaan kerja karyawannya guna mencapai hasil kerja yang maksimal. Skor terendah adalah 3.06 yang terletak pada pernyataan "Pemimpin saya rela mengorbankan kepentingan pribadinya demi kepentingan organisasi”.

Tabel 10.

Deskripsi Jawaban Responden Mengenai Motivasi

\begin{tabular}{|c|c|c|c|c|c|c|c|c|}
\hline \multirow{2}{*}{ No. } & \multirow{2}{*}{ Pernyataan } & \multicolumn{5}{|c|}{ Proporsi Persepsi Responden } & \multirow{2}{*}{$\begin{array}{c}\text { Rata- } \\
\text { rata }\end{array}$} & \multirow{2}{*}{ Kriteria } \\
\hline & & STS & TS & $\mathbf{N}$ & $\mathbf{S}$ & SS & & \\
\hline 1. & $\begin{array}{l}\text { Pekerjaan saya saat ini sudah sesuai } \\
\text { dengan keahlian yang saya miliki } \\
\left(\mathrm{X}_{3.1}\right)\end{array}$ & 0 & 3 & 8 & 16 & 5 & 3,72 & Tinggi \\
\hline 2. & $\begin{array}{l}\text { Penempatan kerja dalam } \\
\text { perusahaan ini sudah sesuai dengan } \\
\text { pengalaman bekerja saya }\left(\mathrm{X}_{3.2}\right)\end{array}$ & 0 & 3 & 8 & 16 & 5 & 3,72 & Tinggi \\
\hline 3. & $\begin{array}{l}\text { Kondisi pekerjaan di dalam } \\
\text { perusahaan sangat menyenangkan } \\
\left(\mathrm{X}_{3.3}\right)\end{array}$ & 0 & 1 & 22 & 8 & 1 & 3,28 & Sedang \\
\hline 4. & $\begin{array}{l}\text { Kondisi pekerjaan di dalam } \\
\text { perusahaan mendorong saya untuk } \\
\text { bekerja lebih baik }\left(\mathrm{X}_{3.4}\right)\end{array}$ & 0 & 0 & 16 & 15 & 1 & 3,53 & Tinggi \\
\hline 5. & $\begin{array}{l}\text { Perusahaan saya memberikan } \\
\text { fasilitas rekreasi seperti liburan ke } \\
\text { tempat rekreasi }\left(\mathrm{X}_{3.5}\right)\end{array}$ & 3 & 19 & 10 & 0 & 0 & 2,22 & Rendah \\
\hline 6. & $\begin{array}{l}\text { Fasilitas rekreasi yang diberikan } \\
\text { perusahaan mampu meningkatkan } \\
\text { semangat kerja saya }\left(\mathrm{X}_{3.6}\right)\end{array}$ & 3 & 19 & 10 & 0 & 0 & 2,22 & Rendah \\
\hline 7. & $\begin{array}{l}\text { Jaminan kesehatan yang diberikan } \\
\text { perusahaan sudah sesuai dengan } \\
\text { kebutuhan saya }\left(\mathrm{X}_{3.7}\right)\end{array}$ & 0 & 0 & 1 & 9 & 22 & 4,66 & $\begin{array}{l}\text { Sangat } \\
\text { Tinggi }\end{array}$ \\
\hline 8. & $\begin{array}{l}\text { Saya merasa terlindungi dengan } \\
\text { adanya jaminan kesehatan selama } \\
\text { bekerja di dalam perusahaan }\left(\mathrm{X}_{3.8}\right)\end{array}$ & 0 & 0 & 1 & 11 & 20 & 4,59 & $\begin{array}{l}\text { Sangat } \\
\text { Tinggi }\end{array}$ \\
\hline & Rata-rata keseluruhan & riabel & $\cdot$ & & & & 3,49 & Tinggi \\
\hline
\end{tabular}

Penjelasan variabel motivasi pada Tabel 10 yang menunjukkan nilai rata rata skor melalui 8 butir pernyataan adalah 3,49. Nilai tersebut berarti motivasi di 
PT. Ganesha Emas Dwipa tergolong tinggi. Kondisi motivasi ini terlihat dari pernyataan "Jaminan kesehatan yang diberikan perusahaan sudah sesuai dengan kebutuhan saya" sebesar 4,66. Skor tersebut berada pada rentang 4,21 - 5,00 dalam kategori sangat tinggi. Hal ini berarti secara keseluruhan responden setuju bahwa jaminan kesehatan yang diberikan oleh perusahaan sudah sesuai dengan kebutuhannya guna meringankan beban biaya hidup mereka. Skor terendah adalah 3,22 yang terletak pada pernyataan "Perusahaan memberikan fasilitas rekreasi seperti liburan ke tempat rekreasi" dan "Fasilitas rekreasi yang diberikan mampu meningkatkan semangat kerja”.

Tabel 11.

Hasil Uji Analisis Regresi Linear Berganda

\begin{tabular}{|c|c|c|c|c|c|}
\hline \multirow[t]{2}{*}{ Model } & \multicolumn{2}{|c|}{$\begin{array}{l}\text { Unstandardized } \\
\text { Coefficients }\end{array}$} & \multirow{2}{*}{$\begin{array}{c}\text { Standardized } \\
\text { Coefficients } \\
\text { Beta }\end{array}$} & \multirow[t]{2}{*}{$\mathbf{T}$} & \multirow[t]{2}{*}{ Sig. } \\
\hline & B & Std. Error & & & \\
\hline (Constant) & 5,932 & 3,224 & & 1,840 & 0,075 \\
\hline Budaya Organisasi & 0,413 & 0,149 & 0,308 & 2,774 & 0,009 \\
\hline Gaya Kepemimpinan & 0,296 & 0,103 & 0,383 & 2,872 & 0,007 \\
\hline Motivasi & 0,292 & 0,073 & 0,342 & 2,606 & 0,014 \\
\hline $\begin{array}{l}\mathrm{R} \\
\mathrm{R}^{2}\end{array}$ & $\begin{array}{l}=0,583 \\
=0,413\end{array}$ & & & & \\
\hline $\begin{array}{l}\text { Adjusted } R^{2} \\
\text { F hitung } \\
\text { Sig F }\end{array}$ & $\begin{array}{l}=0,454 \\
=10,442 \\
=0,001\end{array}$ & & & & \\
\hline
\end{tabular}

Persamaan regresi linear berganda pada Tabel 11 untuk penelitian ini adalah sebagai berikut.

$$
\mathrm{Y}=5,932+0,413 \mathrm{X}_{1}+0,296 \mathrm{X}_{2}+0,292 \mathrm{X}_{3}
$$

Berdasarkan persamaan tersebut, maka variabel budaya organisasi, gaya kepemimpinan transformasional, dan motivasi berpengaruh terhadap komitmen organisasional karyawan di PT. Ganesha Emas Dwipa Cabang Denpasar. $\beta_{1}=$ 0,413 berarti pengaruh budaya organisasi $\left(\mathrm{X}_{1}\right)$ mengakibatkan peningkatan 
Sri Purnamasari, Pengaruh Budaya Organisasi...

komitmen organisasional (Y) karyawan, dengan asumsi variabel bebas yang lainnya dianggap konstan. $\beta_{2}=0,296$ berarti pengaruh gaya kepemimpinan transformasional $\left(\mathrm{X}_{2}\right)$ mengakibatkan peningkatan komitmen organisasional $(\mathrm{Y})$ karyawan, dengan asumsi variabel bebas yang lainnya dianggap konstan. $\beta_{3}=$ 0,292 berarti pengaruh motivasi $\left(\mathrm{X}_{3}\right)$ mengakibatkan peningkatan komitmen organisasional (Y) karyawan, dengan asumsi variabel bebas yang lainnya dianggap konstan.

Berdasarkan Tabel 11 besarnya nilai Adjusted $\mathrm{R}$ square adalah sebesar 0,454 yang artinya sebesar 45,4 persen komitmen organisasional dipengaruhi oleh budaya organisasi, gaya kepemimpinan transformasional, dan motivasi karyawan. Sedangkan sisanya sebesar 54,6 persen dipengaruhi oleh faktor-faktor lain yang tidak dimasukkan ke dalam model penelitian ini.

Tabel 12.

Hasil Uji Normalitas

\begin{tabular}{lc}
\hline & Unstandardize Residual \\
\hline $\mathrm{N}$ & 32 \\
Kolmogorov-Smirnov $Z$ & 0,699 \\
Asymp. Sig. (2-tailed) & 0,714 \\
\hline Sumber : data diolah, 2018
\end{tabular}

Berdasarkan Tabel 12 diperoleh hasil dari Kolmogorov-Smirnov $Z$ sebesar 0,699, sedangkan Asymp. Sig. (2-tailed) sebesar 0,714. Hasil tersebut menjelaskan bahwa model persamaan regresi tersebut berdistribusi normal karena nilai Asymp. Sig. (2-tailed) 0,714 lebih besar dari nilai alpha 0,05.

Tabel 13.

Hasil Uji Multikolinearitas

\begin{tabular}{lcc}
\hline \multicolumn{1}{c}{ Variabel } & \multicolumn{2}{c}{ Colinearity Statistic } \\
\cline { 2 - 3 } & Tolerance & VIF \\
\hline Budaya Organisasi $\left(\mathrm{X}_{1}\right)$ & 0,935 & 1,069 \\
Gaya Kepemimpinan Transformasional $\left(\mathrm{X}_{2}\right)$ & 0,672 & 1,487 \\
Motivasi $\left(\mathrm{X}_{3}\right)$ & 0,637 & 1,570 \\
\hline Sumber : data diolah, 2018 &
\end{tabular}


Berdasarkan Tabel 13 dapat dilihat bahwa nilai tolerance dan VIF dari variabel budaya organisasi, gaya kepemimpinan transformasional, dan motivasi. Nilai tersebut menunjukkan bahwa nilai tolerance untuk setiap variabel lebih besar dari $0,10(10 \%)$ dan nilai VIF lebih kecil dari 10 yang berarti model persamaan regresi bebas dari multikolinearitas.

Tabel 14.

Hasil Uji Heteroskedastisitas

\begin{tabular}{lccccc}
\hline \multirow{2}{*}{ Model } & \multicolumn{2}{c}{$\begin{array}{c}\text { Unstandardized } \\
\text { Coefficients }\end{array}$} & $\begin{array}{c}\text { Standardized } \\
\text { Coefficients }\end{array}$ & \multirow{2}{*}{ t } & \multirow{2}{*}{ Sig. } \\
\cline { 2 - 5 } & $\mathbf{B}$ & Std. Error & Beta & & \\
\hline (Constant) & 3,232 & 1,836 & & 1,760 & 0,089 \\
Budaya Organisasi & $-0,080$ & 0,038 & $-0,371$ & $-2,077$ & 0,097 \\
Gaya Kepemimpinan Trasformasional & $-0,040$ & 0,057 & $-0,148$ & $-0,704$ & 0,487 \\
Motivasi & 0,065 & 0,042 & 0,336 & 1,552 & 0,132 \\
\hline
\end{tabular}

Sumber : data diolah, 2018

Berdasarkan Tabel 14 dapat disimpulkan bahwa nilai Sig. dari variabel budaya organisasi sebesar 0,097, gaya kepemimpinan transformasional sebesar 0,487, dan motivasi sebesar 0,132 . Nilai tersebut lebih besar dari 0,05 yang berarti bahwa tidak terdapat pengaruh antara variabel bebas terhadap absolute residual. Dengan demikian, model yang dibuat tidak mengandung gejala heteroskedastisitas.

Tabel 15.

Hasil Uji F

\begin{tabular}{lccccc}
\hline \multicolumn{1}{c}{ Model } & Sum of Square & Df & Mean Square & F & Sig. \\
\hline Regression & 4,750 & 3 & 1,583 & 10,442 & 0,001 \\
Residual & 36,718 & 38 & 1,311 & & \\
Total & $\mathbf{4 1 , 4 6 9}$ & $\mathbf{3 1}$ & & & \\
\hline
\end{tabular}

Sumber : data diolah, 2018

Berdasarkan Tabel 15, nilai signifikansi $\mathrm{F}$ adalah sebesar 0,001 yang lebih kecil dari $0,05(\mathrm{~F}<\alpha)$ yang berarti variabel bebas yaitu budaya organisasi $\left(\mathrm{X}_{1}\right)$, gaya kepemimpinan transformasional $\left(\mathrm{X}_{2}\right)$, dan motivasi $\left(\mathrm{X}_{3}\right)$ berpengaruh signifikan secara serempak atau bersama-sama terhadap variabel terikat yaitu 
Sri Purnamasari, Pengaruh Budaya Organisasi...

komitmen organisasional (Y) di PT. Ganesha Emas Dwipa Cabang Denpasar, sehingga penelitian ini dapat dikatakan memenuhi uji kelayakan model atau dinyatakan layak untuk digunakan sebagai model regresi.

Tabel 16.

Hasil Uji t

\begin{tabular}{clc}
\hline No. & Variabel & Sig. t \\
\hline 1. & Budaya organisasi & 0,009 \\
2. & Gaya kepemimpinan transformasional & 0,007 \\
3. & Motivasi & 0,014 \\
\hline
\end{tabular}

Sumber : data diolah, 2018

Berdasarkan hasil analisis pengaruh budaya organisasi terhadap komitmen organisasional diperoleh nilai Sig.t sebesar 0,009. Nilai Sig.t 0,009 $<0,05$ mengindikasi bahwa $\mathrm{H}_{0}$ ditolak dan $\mathrm{H}_{1}$ diterima. Hasil ini mempunyai arti bahwa budaya organisasi berpengaruh positif dan signifikan terhadap komitmen organisasional. Berdasarkan hasil uji t dan nilai signifikansi pada variabel budaya organisasi $\left(\mathrm{X}_{1}\right)$ menunjukkan nilai sig. lebih kecil dari 0,05 maka dapat disimpulkan bahwa budaya organisasi $\left(\mathrm{X}_{1}\right)$ berpengaruh positif dan signifikan terhadap komitmen organisasional (Y). Hal ini berarti semakin baik penerapan budaya organisasi maka semakin tinggi komitmen organisasional karyawan, begitu pula sebaliknya semakin kurang baik budaya organisasi maka semakin rendah komitmen organisasional karyawan. Hasil penelitian ini sesuai dengan penelitian yang dilakukan oleh Sari dan Witjaksono (2013), Taurisa dan Ratnawati (2012), Purba (2010), Rosyidah (2012), dan Nugroho (2013) juga menyatakan bahwa budaya organisasi berpengaruh positif dan signifikan terhadap komitmen organisasional. Budaya yang kuat memiliki pengaruh yang kuat dalam pembentukan perilaku anggota suatu organisasi. Semakin banyak anggota yang 
menerima nilai - nilai bersama tersebut, maka akan semakin kuat budayanya. Dengan terciptanya budaya yang kuat, anggota organisasi akan menimbulkan sense of belonging yang dapat menciptakan komitmen terhadap organisasinya. Sehingga budaya organisasi menjadi suatu hal yang penting untuk diperhatikan dalam meningkatkan komitmen organisasional.

Berdasarkan hasil analisis pengaruh gaya kepemimpinan transformasional terhadap komitmen organisasional diperoleh nilai Sig.t sebesar 0,007. Nilai Sig.t $0,007<0,05$ mengindikasi bahwa $\mathrm{H}_{0}$ ditolak dan $\mathrm{H}_{2}$ diterima. Hasil ini mempunyai arti bahwa gaya kepemimpinan transformasional berpengaruh positif dan signifikan terhadap komitmen organisasional. Berdasarkan hasil uji t dan nilai signifikansi pada variabel gaya kepemimpinan transformasional $\left(\mathrm{X}_{2}\right)$ menunjukkan nilai sig. lebih kecil dari 0,05 maka dapat disimpulkan bahwa gaya kepemimpinan transformasional $\left(\mathrm{X}_{2}\right)$ berpengaruh positif dan signifikan terhadap komitmen organisasional (Y). Hal ini berarti semakin baik penerapan gaya kepemimpinan transformasional maka semakin tinggi komitmen organisasional karyawan, begitu pula sebaliknya semakin kurang baik penerapan gaya kepemimpinan transformasional maka akan semakin rendah komitmen organisasional karyawan. Hasil penelitian ini sesuai dengan penelitian yang dilakukan oleh Atmojo (2012),Cacioppe (dalam Kim 2006:40), Kurniawan (2015), Atmojo (2012) dan Dunn et al. (2012) memberikan bukti yang mendukung bahwa perilaku pemimpin transformasional secara positif dan signifikan berhubungan dengan komitmen organisasional. 
Sri Purnamasari, Pengaruh Budaya Organisasi...

Berdasarkan hasil analisis pengaruh motivasi terhadap komitmen organisasional diperoleh nilai Sig.t sebesar 0,014. Nilai Sig.t 0,014 $<0,05$ mengindikasi bahwa $\mathrm{H}_{0}$ ditolak dan $\mathrm{H}_{3}$ diterima. Hasil ini mempunyai arti bahwa motivasi berpengaruh positif dan signifikan terhadap komitmen organisasional. Berdasarkan hasil uji $\mathrm{t}$ dan nilai signifikansi pada variabel motivasi $\left(\mathrm{X}_{3}\right)$ menunjukkan nilai sig. lebih kecil dari 0,05 maka dapat disimpulkan bahwa motivasi $\left(\mathrm{X}_{3}\right)$ berpengaruh positif dan signifikan terhadap komitmen organisasional (Y). Hal ini berarti semakin baik penerapan motivasi karyawan maka semakin tinggi komitmen organisasional karyawan, begitu pula sebaliknya semakin kurang baik penerapan motivasi karyawan maka akan semakin rendah komitmen organisasional karyawan. Hasil penelitian ini sesuai dengan penelitian yang dilakukan oleh Devi (2009), Puspasari (2013), Sanusi (2012), Puspasari (2014) dan Mahmuda (2011) menyatakan bahwa motivasi berpengaruh positif terhadap komitmen organisasional.

Hasil penelitian ini memiliki implikasi teoritis dan praktis. Secara teoritis, hasil penelitian ini menunjukkan bahwa budaya organisasi, gaya kepemimpinan transformasional, dan motivasi karyawan berpengaruh positif dan signifikan terhadap komitmen organisasional. Dengan demikian, hasil penelitian ini memberikan dukungan empiris dan dinyatakan dapat memperkuat hasil - hasil studi terdahulu. Secara praktis, penelitian ini diharapkan dapat memberikan manfaat bagi pemimpin serta karyawan PT. Ganesha Emas Dwipa Cabang Denpasar. Manajemen diharapkan dapat menyesuaikan pekerjaan bagi para karyawannya agar perusahaan mampu mencapai tujuan perusahaan tersebut, 
sehingga meningkatkan komitmen organisasional karyawan di dalam perusahaan. Manajemen juga hendaknya melakukan pendekatan kepada karyawan, misalnya memberikan reward kepada karyawan yang dapat meningkatkan komitmen karyawan di perusahaan tersebut. Manajemen juga harus mampu bersikap adil kepada para karyawannya agar tujuan dari perusahaan tersebut tercapai. Selain itu, manajemen juga harus memperhatikan motivasi karyawan dengan baik, karena karyawan akan merasa semangat mengerjakan tugas mereka apabila manajemen mampu memberikan motivasi yang baik kepada para karyawannya dalam mengerjakan pekerjaan mereka.

\section{SIMPULAN DAN SARAN}

Berdasarkan hasil yang telah dipaparkan, diperoleh tiga kesimpulan, yaitu Budaya organisasi berpengaruh positif dan signifikan terhadap komitmen organisasional di PT. Ganesha Emas Dwipa Cabang Denpasar. Hal ini sesuai dengan hipotesis pertama $\left(\mathrm{H}_{1}\right)$ yang menyatakan bahwa budaya organisasi berpengaruh positif dan signifikan terhadap komitmen organisasional. Gaya kepemimpinan transformasional berpengaruh positif dan signifikan terhadap komitmen organisasional di PT. Ganesha Emas Dwipa Cabang Denpasar. Hal ini sesuai dengan hipotesis kedua $\left(\mathrm{H}_{2}\right)$ yang menyatakan bahwa gaya kepemimpinan transformasional berpengaruh positif dan signifikan terhadap komitmen organisasional. Motivasi berpengaruh positif dan signifikan terhadap komitmen organisasional di PT. Ganesha Emas Dwipa Cabang Denpasar. Hal ini sesuai dengan hipotesis ketiga $\left(\mathrm{H}_{3}\right)$ yang menyatakan bahwa motivasi berpengaruh positif dan signifikan terhadap komitmen organisasional. 
Berdasarkan hasil analisis penelitian, pembahasan dan simpulan terdapat beberapa saran yang dapat diberikan adalah sebagai berikut. Seorang pemimpin diharapkan mampu untuk memberikan kenyamanan dan suasana kondusif dalam bekerja. Hal ini dapat dilihat dengan mampunya karyawan bekerja sama tim, misalnya setiap ada permasalahan dalam tim kerja karyawan selalu menyelesaikan permasalahan yang ada dengan baik. Hal tersebut dapat meningkatkan komitmen organisasional karyawan terhadap perusahaan. Seorang pemimpin diharapkan selalu memiliki sikap yang adil didalam perusahaan dengan cara memberikan kesempatan yang sama bagi para karyawan untuk ikut memberikan masukan untuk pengambilan keputusan.

Dengan demikian, karyawan akan merasa keberadaannya dan merasa lebih dihargai. Hal tersebut dapat meningkatkan komitmen organisasional karyawan terhadap perusahaan. Manajemen diharapkan agar mampu meningkatkan motivasi kerja bagi para karyawannya dengan cara memberikan reward bagi karyawan yang berprestasi di perusahaan tersebut. Selalu menjaga serta memperhatikan motivasi yang diberikan kepada karyawannya akan meningkatkan komitmen organisasional karyawan terhadap perusahaan.

\section{REFERENSI}

Ahmad, M. Wasay, E. \& Malik, S. (2012). Impact of Employee Motivaton on Customer Satisfaction: Study of Airline Industry in Pakistan: Interdiciplinary. Journal of Contemporary Research in Business, Institute of Interdiciplinary Business Research, 4(6).

Ali, A. Abrar, M. \& Haider J. (2012). Impact of Motivation on the working performance of employees - A case study of Pakistan: Global Advanced Research. Journal of Management and Business Studies, 1(4), pp. 126133. 
Ardana, I Komang, Mujiati, Ni Wayan; Utama, I Wayan Mudiartha. (2012). Manajemen Sumber Daya Manusia, Edisi 1. Cetakan Pertama. Yogyakarta: Graha Ilmu.

Azar, M \& Shafighi, A. (2013). The Effect of Work Motivation on Employees Job Performance: International. Journal of Academic Research in Business and Social Science, 3(9), ISSN: 2222-6990.

Bass dan Avolio. (1990). Developing Transformational Leadership: 1992 and Beyond. Journal of European Industrial Training. 14(5), pp: 21 - 27.

Bommer, W.H., Rubin, R. S., \& Baldwin, T. T. (2004). Setting the stage for effective leadership: Antecedents of transfoemational leadership behavior. Journal of The Leadership Quartely, 15(2), pp: 195-210.

Chaudhary, N \& Sharma, B. (2012). Impact of Employee Motivation on Performace (Productivity) in Private Organization: International. Journal of Business Trends and Technology, 2(4).

Chintalloo, S \& Mahadeo, J. (2013). Effect of Motivation Employees Work Performance at Ireland Blyth Limited: Proceedings of $8^{\text {th }}$ Annual London Business Research Conference Imperal Collage, London, UK, 8 ISBN: 9781-922069-28-3.

Christina T.S, (2012), Pengaruh Komitmen Organisasi, Budaya Organisasi dan Keterlibatan Kerja terhadap Kinerja Karyawan BMT. Media Riset Akuntansi, Vol. 2. No. 1.

Colquitt, Jason A, Jeffery A, Lepine., and Michael J. Wesson. (2011). Organizational Performance and Commitment in the Workplace. New York: McGraw- Hill.

Darmawan, H. D. (2013). Prinsip - prinsip Perilaku Organisasi. Surabaya: Pena Semesta.

Devi, Eva Krisdiana. (2009). Analisa Pengaruh Kepuasan Kerja dan Motivasi terhadap Kinerja Karyawan dengan Komitmen Organisasi sebagai Variabel Intervening (Studi pada PT. Semeru Karya Buana Semarang). Universitas Atmajaya. Yogyakarta.

Dunn, M.W., Dastoor, B. and Sims, R.L. (2012). Transformasional Leadership and Organizational Commitment: A Cross - Culture Perspective, Journal of Multidisciplinary Research, 4(1), pp. 124-137.

Febriana, Anggun Tri. (2012). "Analisis Pemetaan Budaya Organisasi Menggunakan Organizational Culture Assessment Instrument Pada PT. Bank Pembangunan Daerah Jawa Tengah". Journal of Diponegoro Business Review, 1(1), pp: 1-15. 
Ghozali, Imam. (2009). Aplikasi Analisis Multivariate dengan Program SPSS. Edisi Keempat. Penerbit Universitas Diponegoro.

Gibson, J.L., J.M. Ivancevich, J.H. Donnelly, R. Konopaske. (2012). Organizational: Behavior, Structure and process. New York: McGraw-Hill,

Indrayanto, A, John, B, Kandy, B, dan Noermijati. (2013). "A case study of transformasional leadership and para - police performance in Indonesi." Policing : An International. Journal of Police Strategies and Management, 37(2)., pp: 373 -388. Emerald Insight.

Iqbal, J. Yusaf, A. Munawar, R. Naheed, S. (2012). Employee Motivation in Modern Organization: Interdiciplinary. Journal of Contemporary Research in Business, 4(3).

Kim, H. (2006). Transformational and Transactional Leadership of Athletic Directors and their Impact on Organizational Outcome Perceived by Head Coached at NCAA Division II Intercollegiate Institutions, Dissertation of Philosophy.

Kinicki, A., R. Kreitner, (2010). Organization Behavior, Key Concept Skills, and Best Practice. New York: McGraw-Hill,.

Kuncoro, Mudjrad. (2009). Metode Riset untuk Bisnis \& Ekonomi Edisi 3. Jakarta: Penerbit Erlangga.

Lok, Peter dan Crawford, John. (2004). The Effect of Organizational Culture and Leadership Style on Job Satisfaction and Organizational Commitment. The Journal of Management Development, (23), pp: 321-337.

Luthans, Fred. (2005). Organizational Behavior. McGraw-Hill, Irwin.

Malayu, S. P. (2007). Manajemen Sumber Daya Manusia. Cetakan Kesembilan. PT. Bumi Aksara. Jakarta.

Maria Angella Widya Puspasari. (2013). Pengaruh Motivasi dan Budaya Organisasi Terhadap Komitmen Organisasi dan Kinerja Karyawan: Universitas Atma Jaya Yogyakarta.

Mckenna, Eugene, (2006). Manajemen Sumber Daya Manusia, Edisi Kedua. Terj. Toto Budi Susanto. Yogyakarta: Penerbit ANDI.

Meyer, John P \& Allen, Natalie J. (1991). A three-component conceptualization of organizational commitment. Human Resource Management Review. 11, pp: 299-326. 
Meyer, John P \& Herscovitch L. (2001). Commitment in the Workplace: Toward a General Model". Human Resource Management Review, 11, pp: 299 326.

Munawaroh. (2011). Pengaruh Kepemimpinan Transformasional dan Transaksional Terhadap Kinerja Guru. Jurnal Ekonomi Bisnis. 16(2).

Muslih, B. (2012). Analisis Pengaruh Motivasi terhadap Kepuasan kerja dan Kinerja Pegawai di PT. Sang Hyang Seri (Persero) Regional III Malang. Jurnal Aplikasi Manajemen, 10( 4), ISSN : 1693 - 5241.

Nelson, Debra L. \& James Campbell Quick. (2012). Principles of Organization Behavior Realities and Challenges, Singapore: McGraw-Hill, International Edition Inc.

Purba Saut. (2010). "Pengaruh Budaya Organisasi, Gaya Kepemimpinan, dan Kepuasan Kerja terhadap Komitmen Organisasi”. Jurnal Manajemen Pendidikan. Staf Pengajar FT. Universitas Negeri. Medan.

Robbins, S. P., and Judge, T. A. (2011). Perilaku Organisasi, Edisi 12, Cetakan 5, Salemba Empat, Jakarta.

Robbins, Stephen P. (2002). Prinsip - prinsip Perilaku Organisasi. Edisi Kelima. Alih Bahasa: Halida, Dewi Sartika. Jakarta: Penerbit Erlangga.

Robbins, Stephen P. (2006). Perilaku Organisasi. Edisi Kesepuluh PT. Indeks. Jakarta.

Robbins, Stephen P., Timothy A. Judge. (2011). Organization Behavior. New Jersey: Person Prentice Hall,.

Robbins, Stephen, (1996), Teori Organisasi, Struktur, Desain dan Aplikasi, Jakarta, Penerbit Arcan.

Sanusi Anwar. (2012). Pengaruh Motivasi Kerja dan Iklim Kominikasi Organisasi terhadap Komiten Organisasi Pegawai Arsip Nasional Republik Indonesia. Jurnal Tesis. Program Studi Magister Komunikasi Fisip UI. Jakarta.

Schein, Edgar H., (2004).Organizational Culture and Leadership, San Fransisco: JosseyBass Publisher,.

Schermerhorn, Hurn, Osborn, and UHL-Bien. (2011).Organizational Behavior. New Jersey: John Wiley \& Sons, Inc.

Siagian, S, p. (2002). Kiat Meningkatkan Produktivitas Kerja. Jakarta: Rineka Cipta. 
Singarimbun, Effendi. (2003). Metode Penelitian Survey. Cetakan Kedua. PT ustaka LP3ES Indonesia:Jakarta.

Sopiah. (2008). Perilaku Organisasi. Yogyakarta: Andi. Stum, David. 1998. Five Ingredients for an Employee Retention Formula. Journal of Human Resources Focus. Vol. 75.

Sugiono. (2010). Metode Penelitian Administrasi. Bandung: CV alfabeta.

Sugiono. (2012). Metode Penelitian Bisnis. Bandung: Alfabeta.

Susanto, A. B. (2011). Management for Everyone Organisasi, Jakarta: Penerbit Erlangga.

Taurisa, Chatarina Melina dan Intan Ratnawati. (2012). "Analisa Pengaruh Budaya Organisasi dan Kepuasan Kerja terhadap Komitmen Organisasional dalam meningkatkan Kinerja Karyawan (Studi pada PT. Sido Muncul Kaliwange Semarang)". Jurnal Bisnis dan Ekonomi. 19(2), pp: 170 - 187.

Tjiptono, F, (2006), Manajemen Pelayanan Jasa. Penerbit Andi. Yogyakarta.

Triana, Kartika Sari dan Andre D Witjaksono. (2013). "Pengaruh Budaya Organisasi terhadap Komitmen Organisasi melalui Kepuasan kerja Karyawan”. Jurnal Ilmu Manajemen. 1(3).

Umar, Husein. (2007). Metode Penelitian untuk Skripsi dan Tesis Bisnis. Jakarta: PT. Raja Grafindo Persada.

Utama, Made Suyana. (2016). Aplikasi Analisis Kuantitatif. Denpasar. Fakultas Ekonomi dan Bisnis Universitas Udayana.

Utami, Iis Torisa. (2010). Pengaruh gaya kepemimpinan transformasional terhadap motivasi kerja karyawan pada PT. Trade Servistama IndonesiaTangerang. Budi Luhur Ekonomi. Jurnal Volume.5. No. 1.

Wicaksono, Y.M. (2014). Analisis Pengaruh Gaya kepemimpinan Transformasional, Motivasi Kerja, dan Komitmen Organisasi terhadap Kinerja Karyawan (Study pada Pusat Koperasi Unit Desa Provinsi Jawa Timur).

Wirawan, I Gusti Putu Nata. (2002). Cara Mudah Memahami Statistik 2 (Statistik Inferensial) untuk Ekonomi dan Bisnis. Denpasar: Edisi Kedua. Keraras Emas.

Yulk, Gary. (2009). Kepemimpinan dalam Organisasi, Edisi 5. Jakarta: Indeks. 